\title{
Serum osteocalcin concentrations in patients with rheumatoid arthritis
}

\author{
P PIETSCHMANN, K P MACHOLD, W WOLOSCZUK, AND J S SMOLEN
}

From the Department of Medicine II, University of Vienna, Ludwig Boltzmann-Institute of Clinical $\vec{\circ}$ Endocrinology, Vienna

SUMMARY Osteocalcin is a non-collagenous bone matrix protein which is released into the circulation and can be measured by radioimmunoassay. Recent studies indicate that serum osteocalcin concentrations are a marker of bone formation. Because bone demineralisation is a common finding in patients with rheumatoid arthritis (RA) the serum osteocalcin concentrations $\rightarrow$ and, in addition, the serum concentrations of 25-hydroxyvitamin D, parathyroid hormone, and 은 calcitonin were measured in 29 patients with RA and in 30 control subjects. Whereas serumosteocalcin concentrations were similar in patients with RA and in control subjects, serum 25-hydroxyvitamin D concentrations were significantly decreased in patients with RA. Serum concentrations of parathyroid hormone and calcitonin in patients with RA and in control subjects were not statistically different. The normal osteocalcin concentrations in patients with RA suggest a normal rate of bone formation in these patients.

Several published reports show that patients with rheumatoid arthritis (RA) may suffer not only from periarticular but also from generalised decalcification. ${ }^{12}$ The mechanisms responsible for this have not been fully clarified; various observations suggest multifactorial processes such as inactivity, the underlying disease itself, and side effects of corticosteroid treatment. ${ }^{3-6}$ The remodelling of bone is a continuous process throughout life; resorption and formation of bone are normally tightly coupled. Changes leading to decreased rates of bone formation or increased rates of bone resorption, or both, may cause a decrease in bone mass. ${ }^{7}$

Serum concentrations of osteocalcin, a noncollagenous bone matrix protein. which can be measured by radioimmunoassay, ${ }^{\circ}$ have been shown to reflect the synthesis anew of osteocalcin by osteoblasts and thus to be a parameter of bone formation." To gain further insights into bone metabolism in RA we measured serum osteocalcin concentrations in patients with RA. In addition, we determined serum concentrations of 25hydroxyvitamin D, parathyroid hormone, and calcitonin in these patients.

Accepted for publication 20 December 1988.

Correspondence to Dr P Pietschmann, Department of Medicine II,

University of Vienna, Garnisongasse 13, A-1090 Vienna, Austria.

\section{Patients and methods}

We studied 29 patients ( 21 female, eight male) with classic or definite $\mathrm{RA}^{110}$; the median age was $\overline{\mathrm{o}}$ 53 years (lower quartile 45 years, upper quartile 59 years). The median duration of disease was 102 months (lower quartile 57 months; upper quartile 153 months). Twenty two patients had functional class II according to Steinbrocker, " seven patients class III. Patients were selected consecutively from those who had had no steroid treatment for at least one week before the study and who had stopped remission inducing drug treatment for at least one month before the study. All patients at the time of this investigation were taking non-steroidal anti- $\frac{D}{0}$ inflammatory drugs (three patients were taking indomethacin, one ibuprofen, one ketoprofen, and $\sigma$ the others diclofenac). Nine patients had never $N$ been treated with glucocorticoids; in six patients N glucocorticoids had been withdrawn more than one $\omega$ year before this investigation: nine patients had been treated with systemic glucocorticoids for $\stackrel{\varphi}{C}$ between one month and one year before the study, $\mathscr{\Phi}$ five patients had received systemic glucocorticoids within one to four weeks before the study; at the time of this investigation, however, no patient was receiving steroid treatment. In all patients with RA serum concentrations of calcium, phosphorus, and creatinine were normal. 
Thirty healthy subjects (20 female, 10 male) served as controls; the median age was 52 years (lower quartile 42 years, upper quartile 68 years).

Serum osteocalcin concentrations were determined with a commercially available radioimmunoassay kit (CIS International, Gif sur Yvette, France) as described in detail. ${ }^{12}$ Serum parathyroid hormone was measured by a radioimmunoassay with mid-region specificity, with synthetic parathyroid hormone (43-68) as tracer and standard. Serum calcitonin was determined with a radioimmunoassay kit purchased from Immuno Nuclear (Stillwater, MN, USA). Serum 25-hydroxyvitamin D was measured by competitive binding protein assay after extraction and $\mathrm{C}-18$ purification (Radiochemical Center, Amersham, UK). All radioimmunoassays had intra-assay coefficients of variation in the useful range of the assays of less than $8 \%$ and interassay coefficients of variation of less than $14 \%$. The minimal detectable dose for osteocalcin was $0.2 \mathrm{ng} / \mathrm{ml}$. The minimal detectable concentration of parathyroid hormone was 20 $\mathrm{pmol} / \mathrm{l}$, of calcitonin $13 \mathrm{pg} / \mathrm{ml}$, of 25 -hydroxyvitamin D $1.5 \mathrm{ng} / \mathrm{ml}$. The results are given as the median value and the lower $\left(25 \%\right.$ point, $\left.\mathrm{Q}_{1}\right)$ and the upper quartiles $\left(75 \%\right.$ point, $\left.\mathrm{Q}_{3}\right)$. The Mann-Whitney $U$ test, the Kruskal-Wallis test, and Pearson correlation coefficient were applied for statistical analysis.

\section{Results}

Figure 1 shows serum concentrations of osteocalcin, 25-hydroxyvitamin $\mathrm{D}$, calcitonin, and parathyroid hormone in patients with RA and in control subjects. Serum concentrations of osteocalcin in patients with RA were similar to those of the control subjects. Serum 25-hydroxyvitamin D concentrations, however, were decreased in patients with RA $(p<0.02)$. In contrast, serum concentrations of parathyroid hormone and calcitonin were not statistically different in patients with RA and in controls.

When serum concentrations of osteocalcin, parathyroid hormone, calcitonin, and 25-hydroxyvitamin $D$ in patients who had never been treated with

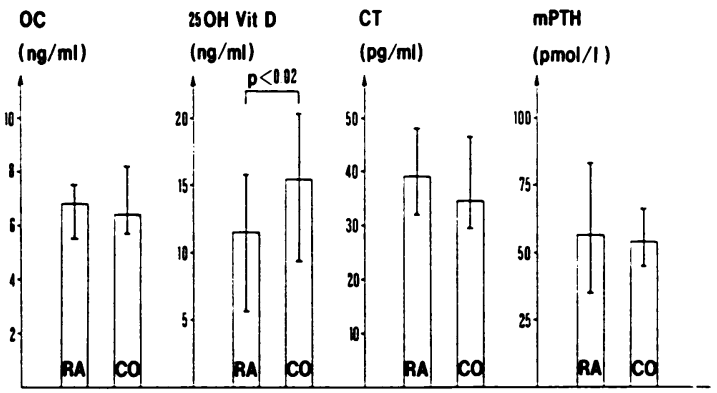

Fig. 1 Serum concentrations of osteocalcin (OC), 25-hydroxyvitamin-D (25OH Vit D), calcitonin $(C T)$, and parathyroid hormone ( $\mathrm{MPTH}$ ) in patients with rheumatoid arthritis (RA) and in control subjects (CO). Data are given as the median value, the lower and the upper quartile.

glucocorticoids were compared with those obtained in patients with previous glucocortoid treatment no significant differences were observed (Table 1).

In patients with juxta-articular demineralisation, shown by $x$ ray examination of the hands, serum concentrations of osteocalcin, parathyroid hormone, calcitonin, and 25-hydroxyvitamin D were not statistically different from those obtained in patients with radiological evidence of diffuse osteopenia (data not shown).

In the patients with RA no correlation between serum osteocalcin concentrations and serum concentrations of parathyroid hormone $(r=0 \cdot 05, N S)$ or 25-hydroxyvitamin D $(r=0 \cdot 15$, NS) were found.

\section{Discussion}

Our data show decreased serum 25-hydroxyvitamin D concentrations but normal serum osteocalcin concentrations in patients with RA. The decreased serum 25-hydroxyvitamin $D$ concentrations in patients with RA is in agreement with some reported data, ${ }^{13-15}$ but in other studies normal concentrations of vitamin D metabolites were found. ${ }^{16} 17$ In contrast with our study van Soesbergen et al found increased serum concentra-

Table 1 Serum concentrations of osteocalcin $(O C)$, parathyroid hormone (PTH), calcitonin (CT), and 25-hydroxyvitamin $D(25 \mathrm{OH}$ Vit $D)$ in the patients with rheumatoid arthritis with no previous glucocorticoid treatment $(A)$ and in those who had stopped taking systemic glucocorticoids for more than one year (B), for between one month and one year (C), and for between one to four weeks (D) before the present study. Results are given as median value (lower quartile-upper quartile).

\begin{tabular}{|c|c|c|c|c|}
\hline & $A$ & $B$ & $C$ & $D$ \\
\hline $\mathrm{OC}(\mathrm{ng} / \mathrm{ml})$ & $7 \quad(6 \cdot 0-8 \cdot 0)$ & $6 \cdot 2(3 \cdot 0-9 \cdot 6)$ & $5.9(4 \cdot 7-7 \cdot 6)$ & $6 \cdot 9(6 \cdot(1-8 \cdot 0))$ \\
\hline PTH (pmol/l) & $54 \cdot 5(34-92 \cdot 5)$ & $68 \cdot 7(34-122)$ & $43 \quad(30 \cdot 8-60 \cdot 8)$ & $71 \quad(42 \cdot 1-83 \cdot 1)$ \\
\hline CT $(\mathrm{pg} / \mathrm{ml})$ & $49 \quad(31 \cdot 8-73)$ & $33 \quad(26-36 \cdot 9)$ & $39 \cdot 6(30 \cdot 8-46 \cdot 7)$ & $41.8(36.4-51.8)$ \\
\hline $25 \mathrm{OH}$ Vit $\mathrm{D}(\mathrm{ng} / \mathrm{ml})$ & $11 \cdot 5(4 \cdot 4-21 \cdot 0)$ & $11 \cdot 7(8 \cdot 2-12)$ & $11 \cdot 5(5 \cdot 1-18 \cdot 7)$ & $8.6(5 \cdot 1-14 \cdot 4)$ \\
\hline
\end{tabular}


tions of parathyroid hormone in patients with RA presenting with vitamin $\mathrm{D}$ deficiency. ${ }^{13}$ This disagreement may be explained by the fact that in the study of van Soesbergen et al 23 of the 29 patients with RA had decreased serum calcium concentrations, whereas in our study serum calcium concentrations were all normal. Thus in the patients of van Soesbergen et al vitamin D deficiency might have been accompanied by secondary hyperparathyroidism, whereas in our group of patients vitamin $\mathrm{D}$ deficiency might have been insufficiently serious to induce secondary hyperparathyroidism. Vitamin D deficiency in RA may be caused by deficient exposure to sun or may perhaps be due to the influence of non-steroidal anti-inflammatory drugs on vitamin $D$ metabolism in the liver. ${ }^{13}$ In various clinical studies serum osteocalcin concentrations have been found to be a marker of bone formation. In conditions with increased bone formation, such as in hyperparathyroidism or in hyperthyroidism, increased serum osteocalcin concentrations have been found. ${ }^{8}$ is In contrast, in conditions with decreased bone formation, such as in low turnover osteoporosis or in patients treated with glucocorticoids, serum osteocalcin concentrations are decreased. ${ }^{\text {is }}{ }^{19}$ In our study serum osteocalcin concentrations in patients with RA were not statistically different from those of control subjects, indicating a normal rate of bone formation in the patients studied. These data disagree with recently published studies, in which both increased and decreased serum osteocalcin concentrations in patients with RA were reported. Ekenstam et al and Riis et al found decreased serum osteocalcin concentrations in patients with $\mathrm{RA}^{2021}$; moreover, Sambrook et al reported decreased serum osteocalcin concentrations in patients with RA of recent onset. ${ }^{22}$ In contrast, Gevers et al found increased serum osteocalcin concentrations in patients with RA, most of whom had been treated with remission inducing drugs. ${ }^{23}$ Franck et al reported increased serum osteocalcin concentrations in patients treated with gold salts or glucocorticoids. ${ }^{24}$ The discrepancies between our findings and recently published data may be explained, at least in part, by the different drugs given in the treatment of RA. Our patients were treated with non-steroidal anti-inflammatory drugs which had been shown to have no influence on circulating osteocalcin. ${ }^{20}$ Chloroquine and penicillamine have been shown to increase serum osteocalcin concentrations in patients with RA. ${ }^{20}$ In the studies reporting increased serum osteocalcin concentrations in RA in contrast with our study most patients had been treated with remission inducing drugs. ${ }^{23}{ }^{24}$ In patients with RA glucocorticoid treatment has been found to decrease serum osteocalcin concentrations, but during gradual reduction of the steroid dosage $\stackrel{\frac{\infty}{\omega}}{\text {. }}$ the osteocalcin concentrations return to pre- $\underset{\vec{D}}{\vec{D}}$ treatment values. ${ }^{20}$

In our study the difference between serum osteocalcin concentrations in patients with glucocor- $\frac{\bar{\sigma}}{\bar{w}}$ ticoids and the concentration in patients who had $\vec{\sigma}$ never received steroids was not statistically signifi- $\triangle$ cant, indicating that the interval between glucocorti- $\infty$ coid withdrawal was sufficiently long for the serum $\overrightarrow{0}$ osteocalcin concentrations to have become normal. $\overrightarrow{\vec{H}}$

In conclusion our data show normal serum osteocalcin concentrations, suggesting a normal osteoblastic activity in patients with RA treated with $\overline{0}$ non-steroidal anti-inflammatory drugs. Osteopenia $\stackrel{\leftrightarrow}{\infty}$ in these patients is thus more probably due to an $\%$ increased bone resorption than to decreased bone of formation.

\section{References}

1 Duncan H, Frost H M, Villaneuva A R, Sigler J W. The osteoporosis of rheumatoid arthritis. Arthritis Rheum 1965; 8: 943-54.

2 Kennedy A C, Lindsay R. Bone involvement in rheumatoidarthritis. Clin Rheum Dis 1977; 3: 403-20.

3 Castillo B A, El Sallab R A, Scott J T. Physical activity, cystic. erosions and osteoporosis in rheumatoid arthritis. Ann Rheum Dis 1965; 24: 522-6.

4 Als O S, Christiansen C, Hellensen C. Prevalence of decreased bone mass in rheumatoid arthritis. Relation to antiinflamma-ō tory treatment. Clin Rheumatol 1984; 3: 201-8.

5 Reid D M, Kennedy N S J, Smith M A, Tothill P, Nuki G. Total body calcium in rheumatoid arthritis: effects of disease activity and corticosteroid treatment. Br Med J 1982; 285: 330-2.

6 Avioli L V. Osteoporosis in rheumatoid arthritis. Arthritis 3 Rheum 1987; 30: 830-1

7 Petersdorf R G, Adams R D, Braunwald E, Isselbacher K J Martin J B, Wilson J D, eds. Harrison's principles of internal medicine. 10th ed. New York: McGraw-Hill, 1983.

8 Price P A, Parthemore J G, Deftos L J. New biochemicale marker for bone metabolism. Measurement by radioimmuno- $-\overline{-}$ assay of bone GLA protein in the plasma of normal subjects and patients with bone disease. J Clin Invest 1980; 66: 878-83.

9 Price P A, Williamson M K, Lothringer J W. Origin of the vita - 글 min K-dependent bone protein found in plasma and its clearance in kidney and bone. J Biol Chem 1981; 256: 12760-6. 을

10 Ropes M W, Bennett G A, Cobb S, Jacox R, Jessar R A. Revision of diagnostic criteria for rheumatoid arthritis. Bulto Rheum Dis 1958; 9: 175-6.

11 Steinbrocker O, Traeger G H, Battermann E C. Therapeutio N criteria in rheumatoid arthritis. JAMA 1949; 140: 659-62.

12 Pietschmann P, Woloszczuk W, Panzer S, Kyrle P, Smolen J S.N Decreased serum osteocalcin levels in phenprocoumon-treated patients. J Clin Endocrinol Metab 1988; 66: 1071-4.

13 van Soesbergen R M, Lips P, van den Ende A, van de尺 Korst J K. Bone metabolism in rheumatoid arthritis compared with postmenopausal osteoporosis. Ann Rheum Dis 1986; $45: \frac{\mathrm{C}}{\mathrm{d}}$ 149-55.

14 O'Driscoll S, O'Driscoll M. Osteomalacia in rheumatoid arthritis. Ann Rheum Dis 1980; 39: 1-6.

15 Wordsorth B P, Vipond S, Woods C G, Mowat A G. Metaboliç bone disease among patients with rheumatoid arthritis. $\mathrm{Br} \mathbb{\mathbb { D }}$ Rheumatol 1984; 23: 251-7.

16 Verstraeten A, Dequeker J. Mineral metabolsim in post $\varrho$ menopausal women with active rheumatoid arthritis. J Rheumag్ tol 1986; 13: 43-6. 
17 Biro H A, Weight V, Henngs V, et al. Comparison of serum 1,25-dihydroxycholecalciferol concentrations in rheumatoid arthritis and osteoarthrosis. Ann Rheum Dis 1982; 41: 257-8.

18 Lukert B P, Higgins J C, Soskopf M M. Serum osteocalcin is increased in patients with hyperthyroidism and decreased in patients receiving glucocorticoids. J Clin Endocrinol Metab 1986; 62: 1056-8.

19 Brown J P, Malaval L, Chapuy M C, Delmas P D, Edouard C, Meunier P J. Serum bone GLA-protein: a specific marker for bone formation in postmenopausal osteoporosis. Lancet 1984; i: 1091-3.

20 Ekenstam E A F, Ljunghall S, Hällgren R. Serum osteocalcin in rheumatoid arthritis and other inflammatory arthritides: relation between inflammatory activity and the effect of gluco- corticoids and remission inducing drugs. Ann Rheum Dis 1986; 45: 484-90.

21 Riis B J, Als O S, Christiansen C, Catherwood B D, Deftos L J. Bone turnover in rheumatoid arthritis. Calcif Tissue Int 1984; 26 (suppl 2): 54

22 Sambrook P N, Ansell B M, Foster S, et al. Bone turnover in early rheumatoid arthritis. 1. Biochemical and kinetic indexes. Ann Rheum Dis 1985; 44: 575-9.

23 Gevers G, Devos P, De Roo M, Dequeker J. Increased levels of osteocalcin (serum bone GLA-protein) in rheumatoid arthritis. Br J Rheumatol 1986; 25: 260-2.

24 Franck H, van Valen F, Keck E, Krüskemper H L. Osteocalcin und Knochenstoffwechsel bei rheumatoider Arthritis und Osteoarthrose. Z Rheumatol 1986; 45: 241-6. 